\title{
TIMOTHY MORTON: BEING ECOLOGICAL (RECENZIÓ)
}

A recenzió szerzője:

Vályi Péter (Drs)

Eszterházy Károly Egyetem

\section{Lektorok:}

Mező Katalin (PhD)

Debreceni Egyetem

Varga Attila (PhD)

Eszterházy Károly Egyetem-OFI

Szerző e-mail címe:

valyipeti@gmail.com ...és további két anonim lektor

Vályi Péter (2020): Timothy Morton: Being Ecological (Recenzió). OxIPO - interdiszciplináris tudományos folyóirat, 2020/1, 103-111. doi: 10.35405/OXIPO.2020.1.103

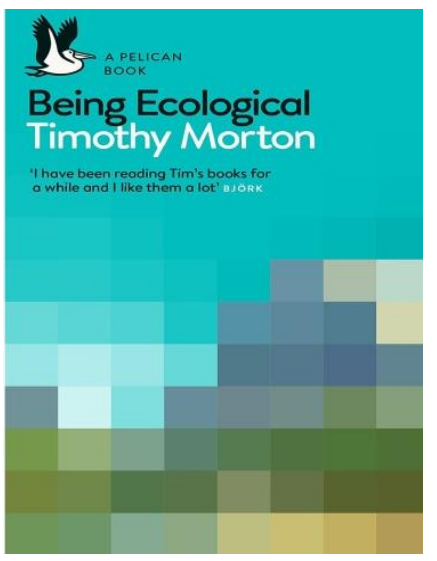

A recenzió alapjául szolgáló mü bibliográfiája: Morton, T. (2018): Being Ecological. Cambridge (MA): MIT Press. 216 oldal ISBN: 9780262537124

Kulcsszavak: ökofilozófia, ökokriticizmus, ökológiai válság, kritikai pedagógia, környezeti nevelés

Diszciplina: ökológia, filozófia, pedagógia

Bibliography of the subject of this recension: Morton, T. (2018): Being Ecological. Cambridge (MA): MIT Press. pp 216 oldal ISBN: 9780262537124

Keywords: ecophilosophy, ecocriticism, ecological disaster, critical pedagogy, environmental education Disciplines: ecology, philosophy, pedagogy

Jelen recenzió egy három részes könyvbemutató-sorozat utolsó eleme, amelynek célja, hogy betekintést biztosítson három kiadványon keresztül a XXI. század egyik legmeghatározóbb filozófusának Timothy
Mortonnak a munkásságába. Ahogyan az előző két recenzió (Vályi, 2019a,b) esetében, most is objektív elemzés közreadása a célunk a személyes vélemények kifejtése helyett. 


\section{A szerző}

Timothy Morton a houstoni Rice Egyetem, Angol Tanszékének professzora, szakterülete eredetileg a romantikus táj, környezeti lírika, azonban 2007 óta ökológiával foglalkozik az objektum orientált filozófia keretein belül. 12 év, 6 könyv és több mint 150 tanulmány megírása után sajátos elméletet és fogalomrendszert hozott létre, amelyekkel egyrészt a filozófiai, másrészt ökológiai diskurzusok megkerülhetetlen alakjává vált.

Munkásságának fogadtatása ambivalens, ez főként eklektikus mash up, tákolt stílusának, tudományos és populáris tartalmakat szintetizáló beszédmódjának köszönhető, amely amúgy az olvasóktól komoly erőfeszítéseket követel, azonban tagadhatatlan, hogy gondolatai, elméletei a művészetektől egészen a kognitív tudományokig inspirálóan hatnak.

\section{A kiadvány témája}

A Being Ecological egy szokatlan könyv ugyan az ökológia, környezetvédelmi ökológia témájú könyvek sorában, azonban Morton munkásságában kevésbé az. Ahogy eddigi könyveiben, úgy most is saját ökológiáról alkotott elméletének kiterjesztésére és alátámasztására törekszik. A provokatív bevezetőben kiderül, hogy a könyv elsősorban azoknak íródott, akik nem foglalkoznak az ökológiával, pontosabban nem törődnek a globális ökoszisztéma, földi eltartóképesség állapotával. Továbbá az is kiderül, hogy ez nem egy újabb information dump, tehát információs szemétlerakat, amely represszióhoz, bűntudatkeltéshez, vallásos rivalláshoz hasonló (Morton 2018). A könyv provokatív neutralitásán túl állít is, méghozzá azt, hogy mindenki, még azok is, akik a legkevésbé sem érdekeltek a föld állapotának a megóvásában, vagy a fenntarthatóság szellemiségének elsajátításában, mindig is ökologikusak voltak a kifejezés eredeti értelmében. Sőt nem volt olyan, hogy ne lettünk volna azok, hiszen együttélésben (coexistence) léteztünk és létezünk napjainkban is, elválaszthatatlanul egymástól, egymás döntéseinek következményeitől terhelt térben, egy bioszférában, egy nagy összekuszált rendszerben (mesh - Morton 2010, 2016, 2018).

A könyv a döntések, választások nehézségéről szól, pontosabban arról, hogy a tudomány, információ kézbesítő rendszere (information delivey system) mennyire nehezíti meg, vagy lehetetleníti el eleve a helyes életmód, stratégiák megválasztásának a kérdését (Morton 2018). A könyv összességében arra a kérdésre keresi a választ, hogy mit, mi mindent jelenthet ökologikusnak lenni a XXI. században. Kitér arra is, hogy a tudomány, big data, információ kézbesítő rendszer mennyire támogatja, vagy éppen gátolja a tuning, azaz hangolódás/ stimulálódás folyamatát, ellenben, ha van hangolás, stimulálás, akkor az a jó irányba történik vagy sem (Morton 2018).

\section{A kiadvány jelentősége, aktualitása}

A kiadvány provokatív, látszólagos neutralitása ellenére mélyen elkötelezett a 
Föld állapotának ügye mellett, még akkor is, ha ez a logika szembe megy a nagy természetvédelmi, ökológiai stratégiák narratíváival (Deep Green Resistance, 2019). Új értelmezési keretbe helyezi, egyben értelmezhetetlenné is teszi azokat a tudományos számokat (éves káros gáz kibocsájtás, hulladákgazdálkodás) amelyek korán sem biztos, hogy alkalmasak teljesíteni azt a célt, amelyek érdekében részben létrejöttek (Morton 2018).

A könyv hasznos felvetéseket tartalmaz a zöld politika, civil szféra, másrészt a pedagógia számára abban a vonatkozásban, miszerint oldhatja az olyan pszichés reakciókat, mint a klímaszorongás, amelyek a globális fenyegetéssel szembeni magatehetetlenség nyomán alakulnak ki (Bolcsó, 2019). Másrészt enyhítheti azon szorongásos reakciókat is, amelyek a fenntarthatósági, környezetvédelmi ajánlások teljesíthetetlenségének okán lépnek fel. Itt fontos megjegyezni, hogy a környezettel szembeni jogsértő, etikátlan magatartás, nem feltétlenül szubjektív döntések eredménye, hanem egy összetettebb szociokulturális kontextusban vizsgálandó kérdés. Például: gondoljunk itt a magyar falvak kiépítettlen szennyvíz elvezető csatornarendszerére. Vagy: interkontinentálissá téve a keretet, a hulladékkal való fütéssel kapcsolatban jusson eszünkbe Ghána, illetve Agbogbloshie, ahol a föként Európából érkező elektronikus hulladék feldolgozása jelent megélhetést a helyi lakosok számára (Beaumont, 2019; Stowell, 2019)!

\section{A kiadvány szerkezete}

A könyv, ahogy a korábi recenziókban említettek is (Vályi, 2019a,b), részben Kant kritikájára, illetve Heidegger munkásságának aktualizálására épít. A mű a cím sugallata ellenére nem az ökologikus lét gyakorlatias leírására törekszik, hanem arra, hogy bemutassa hány és hány megközelítési, értelmezési módja van ennek a bizonyos létezésnek. A „Not another Information Dump”, tehát „Nem egy másik információs szemétlerakat", mint bevezetés, a könyv prepozícionálásáról gondoskodik. Morton a klasszikus ökológiai témájú könyvek tartományán kívülre helyezi jelen kötetét, szokatlan, provokatív eszközökkel.

Az első fejezet „And you may find yourself living in an age of Mass Extinction”, azaz „Lehet, hogy a tömeges kihalások korában találod magad", a térbeliség-időbeliség problémájának a keretezése, amely megkérdőjelezi az egy dimenziós, erre vonatkozó olvasatot és egyfajta ,valaholság” mellett foglal állást.

A második fejezet „....And the leg bones are connected to the toxic waste dump bones," a rész és egész problémájának a feltárásával foglalkozik, és az ökológia holisztikus megközelítésére fókuszál.

A harmadik fejezet „Tuning”, tehát „Hangolás”, stimulálás számos zenei, képzőművészeti példán keresztül szolgáltat illusztrációt az ökológiai akciókhoz, amelyek főként az idővel, dolgok közelségével, egymásrautaltságával állnak szoros kapcsolatban. 
Az utolsó fejezet „A Brief history of ecological thought” az „Ökológiai gondolat rövid története" azoknak a stílusoknak a bemutatása, amelyekben az ökológia témájú könyvek, szakvélemények íródnak.

\section{A kiadvány főbb témakörei}

A kiadvány a következő főbb témaköröket bontja ki:

\section{Ecological information delivery mode és Factoid}

$\mathrm{Az}$ ökológiai információ kézbesítési mód Morton értelmezésében az a műfaj, amelyben a tudomány kommunikál az emberekkel. Jégesőhöz, vagy kőzáporhoz hasonlítja azt, amely sok esetben már akkor, amikor eljut az interpretálókhoz, inadekváttá válik, ezért aktualitása is kérdéses.

Az így kapott információk egyrészt informálnak, másrészt jellegükből adódóan azt is meghatározzák, hogy milyen formában dolgozzuk fel azokat. Az információ kézbesítési mód nemcsak az információ tárgyát hordozza, adott stílusban tálalva azt, hanem magát az interpretátort is pozícionálja (Morton 2018). Például: az emberi hübrisz nyomán kialakuló krízis elbeszélése a bűnös ember szerepkörébe pozícionálja a befogadót.

Morton szerint ez a mód az, amely arról gondoskodik, hogy az úgynevezett „factoid”-ok, azaz módosult tények az irányítás, represszió, bűntudatkeltés eszközévé váljanak. A módosított tények, tényeknek látszanak, azonban van saját „1́zük, egyfajta aromájuk”, amelyek által többnek akarnak látszani szimpla igazság- nál. Így nemcsak tudatnak velünk valamit, de azt is megmondják, hogy éljük meg azt, amit éppen megtudunk.

\section{PTSD}

Freudi nézőpont szerint a poszttraumatikus stressz szindróma (PTSD) miatt álmodók újra és újra átélik álmaikban a tragédiát/traumatikus eseményt. Freud arra a következtetésre jutott, hogy ez, egyfajta öröm forrása, hiszen a beteg tudván, hogy mi vár rá, álmában egy, a traumatikus sokkot megelőző időpontra helyezheti magát, ahonnan (már) felkészülhet az ôt érő, egyben elkerülhetetlen traumatikus élmény újbóli bekövetkezésére, védelmi buborékot vonva így maga köré. Ez, egyben a félelem érzet egy finomabb ,irtózatos" típusát jelenti a traumatikus helyzetek során tapasztalt megrekedt „szorongással” ellentétben (Morton 2018).

Morton PTSD álmodóhoz hasonlóan értelmezi azt, ahogy a tudomány, globális válságról szóló jelentéseivel szembesülünk. Minden egyes alkalommal újra és újra átéljük a traumát, ezért egy a traumát megelőző időpontra próbáljuk visszahelyezni magunkat. Így az alkalmazott stratégiáink is ezt a rekonstrukciós (jelen esetben természeti, környezeti rekonstrukciós) célt szolgálják (Morton 2018).

\section{Tuning}

A hangolás/stimulálás sokat használt kifejezés a műben, de külön fejezetet is kap a könyvben. A ,tuning” röviden az a folyamat, amely az ökologikussá válás állapotát teremti meg. 
A „tuning” egyrészt folyamatot jelöl, amennyiben a helyes információkat kapjuk, amelyek mentén valóban eleget tehetünk annak az ökológiai imperatívusznak, amelyet mindezidáig az antropocentrikus világkép jóvoltából félreértelmeztünk. Másrészt Morton által használt eszköz arra, hogy zenei, képzőművészeti példákon keresztül ráhangolja az olvasót az ökologikus lét valódi jelentésére.

Kiemelt példa az „Ice watch” (Eliasson, 2015) köztéri installáció, amely Grönlandról Koppenhágába, Párizsba, Londonba szállított hatalmas jégtömbökből állt (össztömeg: 80 tonna), amelyeket kör alakba rendezve lehetett megtekinteni. Az installáció az idő alternativitását, kiterjedésének relativitását dolgozta fel, egyrészt a jég olvadása által, másrészt a jégtömbök belsejében tisztán látható egymásra rakódott, tömörített rétegeken keresztül, ahogy Minik Rosing, a projektben szintén résztvevő geológus fogalmaz (Zarin, 2015).

\section{Szubjektív áttekintés, pedagógiai alkalmazhatóság}

Aki esetleg arra számít, hogy Morton hatodik könyvéből, (amely az ökologikus, vagy ökológiai létezés leírására törekszik) konkrét ajánlások, stratégiák olvashatók ki, arra vonatkozóan, hogy miként valósítható meg a könyv címében feltüntetett állapot, csalódni fog.

A könyv egyrészt összegzés, megtalálható benne minden eddigi nagy témakör (Hipertárgy és Sötét Ökológia teória), amelyeknek Morton korábban önálló kötetet biztosított, másrészt, sakkos műszóval élve egyfajta sáncolás is, amelyre Morton külön fel is hívja az olvasó figyelmét. Tény, hogy a korábban (Morton 2010, 2013, 2016) kiadott könyveivel ellentétben a Being ecological könnyebben olvasható, csekélyebb az interdiszciplináris kiszögelések száma, ezért az olvasó kevésbé zökken ki a gondolatmenet követése során.

Formátum tekintetében is eltér ez a mű az előző kiadványoktól: kevésbé tekintélyes, zsebkönyvre emlékeztet, amit az ember segédletként, vagy, ahogy ő maga fogalmaz guide-ként használhat.

A könyv fő motívuma, egyben állítása az, hogy mindig is ökologikusak voltunk, sosem voltunk nem czok a szó eredeti értelmében (Morton 2018a,b). A kiadvány lényegében több mint 200 oldalon keresztül, a tudományos adatok tudományfilozófiai, illetve objektum orientált kritikájával, majd az életformák összekuszáltságával, ökológiai témájú tudományos írások műfajával, szintén azok kritikai vizsgálatával foglalkozik.

Személy szerint nem tapasztaltam heurisztikus élményt akkor, amikor arról olvastam, hogy egy bolygón, egy bioszférában élünk, egymás döntéseinek következményeitől terhelt közös térben. Gondolok itt a szomszéd avarégetésére, vagy akár Csernobilra. A jog és kötelezettség, felelősség kérdésköre alapvetően nem újdonság számomra, hanem ismert, de máig megoldatlan probléma. Sőt, akkor sem láthattam tovább annál, amit már amúgy 
is tudtam, amikor arról oolvashattam, hogy a szükségszerū, szolidáris viszony emberi és nem emberi lények között a házikedvencek példáján keresztül ragadható meg a legegyszerűbben. Egyrészt a két macskámnak köszönhetően tudom, hogy milyen a nem érdek, vagy nem gyakorlati alapú viszony nem emberi és emberi lények között. Biodinamikus, vegyszermentes közösségi kertészként azt is tudom, hogy a kert maga is életformák integrációjáról, dezintegrációjáról szól, ami egészen addig a pontig, ameddig a tudomány nem fejti meg az egyes kártékony tényezők, kártékony tevékenysége mögötti mélyebb működést, így is marad. Amenynyiben a kiadvány tartalmilag erre a szintre korlátozódna, valóban azt mondanám, hogy ez kevés, azonban arra koránt sem adhat okot, hogy olyan személyeskedő, sokkal inkább az író személyére, mintsem a műre reflektáló kritikának adjon teret, mint ami Adam Dickerson írásában olvasható (Dickerson, 2019).

Azonban Morton esetében ez szerencsére nem jellemző. A cím által sugallt, azonban beteljesületlen tartalom ellenére azonban van a könyvnek egy olyan szála, egyben premisszája, amely mindenféleképpen fontos a pedagógiai kutatás, környezeti nevelés számára is. A szál az ökológiai, környezetvédelmi írások stílusvizsgálata, illetve tudományos abszolútitás objektum orientált kritikája.

A vizsgálat a következő fogalmak mentén értelmezi az ökológia témájú szöveg és ember viszonyát: ökológiai információ kézbesítési mód, az általa szállított dizájnolt (készített, egyfajta „célsággal” rendelkező aktív cselekvő) tények, információs szemétlerakat és ezek által generált poszttraumatikus stressz. E fogalmakat fentebb már érintettük, ezért itt erre külön nem térünk ki ismét, ehelyett a pedagógia területén való kontextualizálásukra, aktualizálásukra célszerű fordítani a figyelmünket.

Azt már tudjuk, hogy a globális felmelegedéssel szemben tapasztalt magatehetetlenség pszichés reakciókat válthat ki (ez az úgynevezett klímaszorongás és annak társjelenségei), amellyel már a magyar média, tudomány és iskolák is foglalkoznak (lásd: Bolcsó, 2019). Azt is tudjuk, hogy az alkalmazott, klinikai pszichológia egy szakága a különféle környezeti, természeti katasztrófák túlélőinek vizsgálata során szintén foglalkozik a poszttraumatikus stressz betegség ezen speciális típusával (Hayes és tsai, 2018). Morton érvelése mentén azonban az derül ki, hogy az ökológiai, környezetvédelmi információk inkonzisztens áradata (amely adatok sokszor már elavultak, abban a pillanatban amikor eljutnak hozzánk), Freud, poszttraumatikus stressz betegek vizsgálata során megállapított diagnózisával mutat hasonlóságot.

Ha Morton érvelése helytálló, egyrészt az információk, ajánlások az irányítás eszközévé is válnak (például: környezetvédelmi imperatívuszok, azok által megfogalmazott életmód stratégiák) másrészt a sorozatos információs traumatizálás által a PTSD során megfigyelt reakciók (például: regresszió, dezorientáltság) lépnek fel és válnak konstanssá. Morton ebből azt a 
következtetést vonja le, hogy az adatok, információk, továbbá az informálás ezen típusai nem alkalmasak a szükséges, ökologikus, tudatos szemléletmód kialakítására, és az arra való stimulálásra sem. Ellenkezőleg, repetitív és regresszív reakciót váltanak ki, amelyek önismétléshez, téves problémafelismeréshez és problémamegoldáshoz vezetnek (péládul: a természet rekonstrukciójnak vágyához, megóvásának kényszeréhez, szorongáshoz).

Ahogy arról már volt szó, a kiadvány számos keretezési lehetőséget és kérdést vet fel, amelyek relevánsak a pedagógia dimenziója számára. Az alábbiakban ezek közül szerepeljen itt néhány példa:

a) Mivel a klímaszorongás, mint terminus már a pszichológia, pedagógia tudományának kánonjába is bekerült, talán kezelhetővé, megelőzhetővé válhat Morton kritikai olvasás elméletének felhasználása által. Egyszerű, nyelvi, nyelvtani irodalmi szövegelemző gyakorlatok által, úgy, hogy arra fókuszálunk, hogy az egyes tudományos tudósítások, környezetvédelmi ajánlások, médiaipari termékek, hírek milyen prepozíciót teremtenek az olvasóknak az interpretálás során. Azon túl, hogy egy szöveg közölni kíván valamit, megvizsgálhatjuk, hogy milyen lehetőséget, vagy szükséges teret biztosít az értelmezésre, illetve mennyire kényszerítő, determinisztikus. A szövegek értő értelmezésén jócskán túlmutató, mélyebb analízis segíthet a szorongásos tünetek megelőzésében, segíthet átlátni és megérteni azokat a finoman hangolt mechanizmusokat, amelye- ket „gyakorlott” hír- és információfogyasztóként az ember ignorál.

b) Tény, hogy a tankönyvek, a nemzeti Alaptanterv (NAT), a helyi tantervek nem traumatizálják tendenciózusan a globális felmelegedést, vagy a globális válság bármely aspektusát, azonban az is tény, hogy az információk, hírek elérhetősége, gerilla jellege számos olyan tartalmat helyez a diákok közvetlen közelségébe az online tér, okos eszközök által, amelyek helyes vizsgálatának, értelmezésének hiánya komoly problémákhoz, félreértelmezésekhez vezethet.

c) A könyv egy másik értelmezési kerete a kötelesség és lehetőség arányainak vizsgálata környezetvédelmi, fogyasztói szokások, életmódreformok perspektívájában a pedagógus kutatás számára. Ahogy arra Szvetelszky Zsuzsanna is helyesen felhívja a figyelmet kritikai írásában, a környezet károsító, etikátlan magatartás sok esetben nem szubjektív döntések eredménye, hanem adott, főként gazdasági, társadalmi beágyazottságú kérdés (Szvetelszkyre hivatkozik: Takács-Sánta, 2007). Ezért jogosan merülhet fel a kérdés, hogy a globális folyamatokkal szembeni magatehetetlenség generálta szorongás, klímaszorongás valóban az egyetlen módja-e a pszichés tüneteknek. vagy létezik-e egy másik az egyéni tőkét, cselekvőképességet meghaladó ajánlások, előírások teljesíthetetlensége mentén kibontakozó más típusú egyéni pszichés tünetegyüttes. 


\section{Ajánlás}

Morton eddigi művei közül ez talán az a darab, amelyet széles körben merek ajánlani mindazoknak, akik próbálnak eligazodni napjaink ökológiai diskurzusaiban, vagy azon fáradoznak, hogy eleget tegyenek egy belső, vagy külső késztetésnek az ökologikus létezés vonatkozásában. Ha konkrétumokkal nem is szolgál a könyv, abban mindenféleképpen nagy segítséget nyújt, hogy megértsük a szövegek, főként a válságkezelésről szóló szövegek nem egyenlők a szimpla tájékoztatással.

\section{Irodalom}

Beaumont, P. (2019): Rotten eggs: e-waste from Europe poisons Ghana's food chain. The Guardian, 2019.04.24. Letöltés: 2019.11.02. Web: https://www. theguardian.com/global-development /2019/apr/24/rotten-chicken-eggs-ewaste-from-europe-poisons-ghanafood-chain-agbogbloshie-accra

Bolcsó D. (2019): A klímakatasztrófa legyőzéséhez saját magunkkal kell szembenéznünk. Index. 2019.08.06. Letöltés: 2019.11.02. Web: https://index.hu/techtud/2019/08/0 6/klimavaltozas_klimakatasztrofa_kli maszorongas_okogyasz_kornyezetved elem_pszichologia/

Dickerson A (2019) Damaging thinking: A review of Timothy Morton's Being Ecological. The Ecological Citizen, 2019, Vol. 2, 198-199Letöltés: 2019.11.02. Web: https://www.ecologicalcitizen. net/pdfs/v02n2-15.pdf
Eliasson, O. (2015): Ice watch. Letöltés: 2019.11.02. Web: https://olafur eliasson.net/archive/artwork/WEK10 9190/ice-watch

Hayes, K., Blashki, G., Wiseman, J., Burke, S., \& Reifels, L. (2018): Climate change and mental health: risks, impacts and priority actions. International Journal of Mental Health Systems, 12, 28. doi: 10.1186/s13033-018-0210-6 Letöltés: 2019.11.03. Web: https:// www.ncbi.nlm.nih.gov/pmc/articles/ PMC5984805/

Morton, T. (2016): Dark ecology For a Logic of Future Coexistence. New York: Columbia University Press

Morton, T. (2018a): Being ecological. Cambridge (MA): MIT Press

Morton, T. (2018b): Being ecological RSA Replay. Letöltés: 2019.11.02. Web: https://www.youtube.com/watch?v= d_5UWI-SEVE\&t $=900 \mathrm{~s}$

Nemzeti Alaptanterv. Letöltés: 2019.11.03. Web: https://www.oktatas2030.hu/ wp-content/uploads/2018/08/anemzeti-alaptanterv-tervezete_2018. 08.31.pdf

Stowell, A. (2019): How potential of massive e-waste dump in Ghana can be harnessed. The Conversation, 2019.09.03. Letöltés: 2019.11.01. Web: https://theconversation.com/howpotential-of-massive-e-waste-dump-inghana-can-be-harnessed-121953

Takács-Sánta A. (szerk.) (2007): Paradigmaváltás?! Kultúránk nébány alapvetó meggyözódésének újragondolása. L'Hamattan, Budapest 
Vályi Péter (2019a): Timothy Morton: The Ecological Thought (Recenzió). OxIPO - interdiszciplináris tudományos folyóirat, 2019/3, 95-101. doi: 10.35405/OXIPO.2019.3.95 Letöltés: 2019.11.06. Web: http://www. kpluszf.com/assets/docs/OxIPO/Ox IPO_2019_3_095_Valyi.pdf

Vályi Péter (2019b): Timothy Morton: Hyperobjects, Philosophy and Ecology after the End of the World
(Recenzió). OxIPO - interdiszciplináris tudományos folyóirat, 2019/4, 79-88. doi: 10.35405/OXIPO.2019.4.79

Zarin, C. (2015): The artist who is bringing icebergs to Paris. The New Yorker. 2015.12.05. Letöltés: 2019.11. 01. Web: https://www.newyorker. com/culture/culture-desk/the-artistwho-is-bringing-icebergs-to-paris 